\title{
Man's Attitude Towards Animals Within the Context of Gender, Age, Place of Living, Eating Habits, and Worldview in Slovakia
}

\author{
Stosunek człowieka do zwierząt na Słowacji w zależności od płci, wieku, miejsca zamieszkania, \\ nawyków żywieniowych i światopoglądu
}

\author{
Ján Kaliský, Lada Kaliská \\ Faculty of Education, Matej Bel University in Banská Bystrica, Slovakia \\ ORCID JK https://orcid.org/0000-0001-6006-7408; LK https://orcid.org/0000-0001-9700-5980 • jan.kalisky@umb.sk \\ Received: 24 Oct, 2021; Revised: 30 Nov, 2021; Accepted: 6 Dec, 2021
}

\begin{abstract}
The ecological values or environmental competency development is currently an important topic. Attitude, relationship, love, or respect for nature can be identified, within several theories by various diagnostic tools, though they might be so general as to not cover fully man's true attitude towards animals. The study discusses the characteristics of the author's questionnaire of the human-animal relationship, AniRe-Que (15), based on the ecological theory of bio-centric egalitarianism, covering non-human beings' respect and consideration. The Questionnaire of Ecocentric and Anthropocentric Attitudes Towards the Environment (Thompson and Barton 1994), adapted by Siegrist (1996), was used to determine the construct validity of the author's questionnaire. Both tools were used to search for respondents' attitudes towards animals ( $N=937$ ) in the context of their gender, age, residence, eating habits, and worldview. The research study is of a correlation-differential study design. The most important findings were that the attitude towards nature, expressed in general, does not completely coincide with the attitude towards animals, leading to the hypothesis that not all natural beings are treated with equal respect by man. The self-reported respect for animals, was significantly lower than the respect for nature assessed by the ecocentric environmental attitude. The diagnostic tools thematising only nature in its general (complex, synthesising) context, seem to be insufficient to determine a respondent's attitude towards animals. A man might protect nature, but $s /$ he can care far less about the animals.
\end{abstract}

Keywords: attitude to nature, relationship to animals, moral values diagnostics, animal respect questionnaire (AniRe-Que)

Streszczenie: Walory ekologiczne oraz rozwój kompetencji środowiskowych są obecnie ważnymi zagadnieniami. Postawę, związek, miłość czy szacunek do przyrody można badać, uwzględniając kilka koncepcji teoretycznych za pomocą różnych narzędzi diagnostycznych. Narzędzia te pozwalają określić prawdziwy stosunek człowieka do zwierząt. W opracowaniu tym omówiono charakterystykę autorskiego kwestionariusza relacji człowiek-zwierzę AniRe-Que (15) opartego na ekologicznej teorii biocentrycznego egalitaryzmu obejmującego szacunek i respekt nawet dla istot pozaziemskich. Do określenia trafności kwestionariusza wykorzystano Kwestionariusz Ekocentrycznych i Antropocentrycznych Postaw wobec Środowiska (Thompson i Barton 1994), zaadaptowany przez Michaela Siegrista (1996). Oba narzędzia posłużłły do poszukiwania postaw respondentów wobec zwierząt ( $\mathrm{N}=937$ ) w kontekście ich płci, wieku, miejsca zamieszkania, nawyków żywieniowych i światopoglądu. Badanie ma charakter badania korelacji i różnic. Najważniejszym wnioskiem wypływającym z tych badań jest fakt, że ogólnie deklarowany stosunek do przyrody nie w pełni pokrywa się z postawami względem zwierząt. To zaś prowadzi do hipotezy, że nie wszystkie istoty żywe traktowane są przez człowieka z równym szacunkiem. 
Badania wykazały, że deklarowany szacunek do zwierząt był istotnie niższy niż szacunek dla przyrody oceniany przy pomocy narzędzia uwzględniającego ekocentryczne nastawienie środowiskowe. Narzędzia diagnostyczne ujmujące przyrodę jedynie w jej ogólnym (złożonym, syntetyzującym) kontekście wydają się niewystarczające do określenia stosunku respondenta do zwierząt. Człowiek może bowiem ogólnie chronić przyrodę, jednocześnie nie troszcząc się o zwierzęta.

Słowa kluczowe: stosunek do przyrody, stosunek do zwierząt, diagnostyka wartości moralnych, kwestionariusz szacunku do zwierząt (AniRe-Que)

\section{Introduction - theoretical framework}

Norms regulate the behaviour of man who, through them, orients himself in various meanings, and articulates his worldview paradigm. A certain metaphysical hierarchy expresses nature and animal position in this paradigm. This hierarchy might not be conscious, though a man acts according to it unconsciously. Our sociological survey based on a questionnaire of our provenience, focuses on man's attitudes towards animals. By the term "animal", we mean animals other than humans (which is the broader content of this term). According to Nakonečný (1998), we define an attitude as an "evaluation state". Having an attitude towards something means taking an evaluative position towards a certain object. While tools for a nature attitude assessment exist in the professional literature (Thomson and Barton 1994; Siegrist 1996; Dunlap and Van Liere 1978; Milfont and Duckitt 2010; Krajhanzl 2014), tools to assess the attitudes towards animals are less common (Herzog et al. 1991; Pirrone et al. 2019). However, research based on nature assessment in general, provides only indirect information about man's perceived attitudes towards animals. Experiencing the beauty of nature, awareness of its fragility and damage, or the number of visits into the natural environment (which are common items of nature attitude questionnaires), may not be related to the perception of animals at all, in the minds of respondents, who do not have to talk about their relationship to the animals. The animals can only represent a "backdrop" function for man's own non-animal activities, (possibly activities with animals are in an instrumental, utilitarian form). Therefore, the study's aim is to explain the theoretical background of a questionnaire "Animal Respect" (An$\mathrm{iRe}$-Que/15/) of our own provenience, and to analyse the findings in the context of five sociological factors, i.e., age, gender, eating habits, worldview, and place of living.

Respect in the context of ecological values has a central place in the conceptualisation of attitudes towards animals and finds its widest application as respect for life. Respect for life begins with the feeling of amazement with life itself, with understanding that life is endowed with meaning and value, that it is a goal in itself. Human will to live that has become a will acknowledging other wills to live. According to Schweitzer (1974), life has value in itself - both a human and animal one. Bio-centrism (or zoo-centrism) understands each individual organism as a teleological centre of life, heading towards its own good (similar to Taylor 1986). And good for "it" is everything that keeps him/ her/it in existence, developing the possibilities and contributing to the prosperity. The bearer of life, thus, has an inherent value considered to be a goal in itself, and man is able to show respect for "it". Taylor took an academic anchoring of Schweitzer's ethics of respect for life, to be academically conceptualised by him, and in a study Respect for Nature (1986), he proposed the "ethics of respect for nature" as a parallel to the deontological ethics of interpersonal relationships, and establishes respect, in terms of respect for a living being. Taylor introduces the term "the good of an organism," according to which, good is what "makes/ acts well" for any living being in the sense 
of supporting and protecting life (Skýbová $2011,104)$. It is a matter of developing one's own potentials.

Taylor (according to Kolářský, 2011,) distinguishes two meanings of the term 'interest': to have an interest (associated with wanting), and to be in someone's interest (associated with good). He considers the latter meaning to be morally relevant. The content of the first meaning, for example, does not prevent a man from harming his health by smoking. While animals intuitively know what is biologically good for them, man often does not know. However, man shares the same origin with animals, s/he is a random biological and last-coming being, depending on another life (the opposite way is not true), so $\mathrm{s} /$ he is not a privileged member of the earthly life community: "The idea that humans are the ultimate goal of the evolutionary process is absurd; as the rest of nature would wait for us to come and applaud us, when we have finally arrived". Taylor also ends up in egalitarianism, asking man to treat non-human organisms "always as having a purpose in themselves, never only as means” (Kolářský 2011, 60), and describes man's belief in the uniqueness of him/her, as an unjustified prejudice. For if we claim that man is unique because $\mathrm{s} /$ he has abilities that non-human life does not have, s/he ignores that non-human life has abilities that a man does not have. Or, if we claim that people are superior because their abilities are more valuable (for example, mathematical abilities before running fast), this evaluation is illegitimate, because it derives value only from the perspective of a human life. Or, if we disregard these two claims, and base man's superiority on being born human (as a noble species with a greater intrinsic value), we are displaying an arbitrary prejudice that is analogous to that of the (medieval) nobility, who thought that it was more valuable than the peasants, due to their blood rights. This is the core of Taylor's bio-centric egalitarianism; humans belong to the terrestrial community of life, in the same sense as other organisms, humanity is an integral part of the bio-sphere, and every organism is a unique individual, who strives for "its" own good.

Apart from bio-centric egalitarianism, our second ethical starting point is to understand an animal as a natural entity with its own (i.e., innate) value, as "subjects of life", as an American philosopher, Tom Regan, described it correctly. All subjects of life have the same innate or intrinsic value. Again, this is an egalitarian position, because it does not introduce hierarchy into the animal kingdom, and Regan's position is a "position of law." From this point of view as well, it will then be immoral to behave without respect to one who is the bearer of such an intrinsic value, that is, to a subject, to an individual. The resulting equality is that all animals are living subjects, conscious subjects that can thrive or suffer. Prosperity (quality of life and self-realisation) is important for the bearer of that life, regardless of the usefulness to others. The life experiencing subject is, thus, a goal in himself/herself, a person, and should be given his/her rights (Regan 1985). We must grant them these rights because "their body, their soul, their liberty, their welfare, their life belongs to them, and not to us, because the animals we eat, we use in science, we hunt and exploit in various ways, lead their own lives. This life is important to them. ... even animals are someone, not something ... they have their own biography and not just biology." Life matters no matter how useful it may be to someone else. "We want and prefer something, we think and feel something, we remember and expect something. And all of these dimensions of life - our taste and pain, our joy and suffering, our satisfaction and our frustration, our future life or premature death - this all creates a difference in the quality of our life as we experience and feel it as an individual. And the same is true for animals ... we must also regard them as the experiencing and feeling subjects of life with their own intrinsic value." (Regan 1997, 42-43). While traditional ethics seeks boundaries in the realm of human life and human relations, 
the ethics of respect for life teaches us respect for every form of life, teaches us compassion for all forms of life, and assumes that the secret of life is too great for man, and that its value is beyond man's judgmental abilities.

Respect is the opposite of control and manipulation (which are technical values) and is not equated with (religious) subordination. If I have respect for someone or something, it means that I respect him/her, appreciate, accept, and see (acknowledge) his/her dignity. The opposite actions would then, for instance, be: contempt, defamation, slander, neglect, indifference, humiliation, and even forms of open aggression, abuse, bullying, harm, destruction. Any manipulation breaks down with respectful treatment, because then we treat the other one as a means, or a tool, to achieve our own goals. In Kant's statement, "manipulation is a violation of a categorical imperative undermining dignity". It is the experience of life as an end in itself, and a goal pushing us into an ecological context, as well (despite the fact that Kant only thought about his relationship to other people).

We briefly introduced the theoretical basis of egalitarian zoocentrism as an attitude towards animals (which is based on respect). There are no sociological or diagnostic tools to assess this respect towards animals in the Czecho-Slovak scientific research setting. Based on these theoretical starting points of egalitarian zoocentrism, we created and presented our diagnostic tool "Animal Respect Questionnaire", abbreviated AniRe-Que (15) (Kaliský and Kaliská, 2020) with proven construct and criterion validity, and inner reliability. In this study, in addition to its theoretical background, we present findings in the context of gender, age, residence, eating habits, and worldview on a sample of 937 respondents. We also used The Questionnaire of Ecocentric and Anthropocentric Attitudes Towards the Environment (Thompson and Barton, 1994) edited by Siegrist (1996) titled: Fragebogen zur Erfassung der ökozentrischen und anthropozentrischen Umwelteinstellung (FEOAU), identifying three dominant environmental orientations towards nature, distinguishing between anthropocentric, ecocentric or apathic orientation.

\section{Research Method}

On the basis of theoretical findings described above, and as a further need of the AniRe-Que(15) validation process, the present study's aims were to analyse the relationship between animal respect to three environmental orientations within the other contextual variables, i.e. gender, age, worldview and a place of living.

We questioned the following seven questions:

- RQ1: Can we support the construct validity of AniRe-Que(15), in the context of three environmental orientations?

- RQ2: Are there any significant gender differences in animal respect (R-score), and three environmental attitudes from FEOAU?

- RQ3: Is there any significant difference between the ecocentric attitude from FEOAU and R-score from AniRe-Que(15), for each participant and for both genders?

- RQ4: Are there any significant differences between three age groups in the animal respect score and three environmental orientations?

- RQ5: Can we support the criterion validity of AniRe-Que(15), in the context of omnivores and vegetarians?

- RQ6: Are there any significant differences in animal respect (R-score), and three environmental attitudes from FEOAU, in the context of a participant's worldview?

- RQ7: Are there any significant differences in animal respect ( $\mathrm{R}$-score), and three environmental attitudes from FEOAU, in the context of a participant's place of living? 


\section{Research sample}

The research sample, based on an occasional sampling procedure, consisted of 936 respondents ( $55 \%$ of females, $M_{\text {age }}=24.6$; $\mathrm{SD}=10.2$ ) of various professional fields (e.g., students, teachers, barbers, technicians, vets, sportsmen and women, counsellors, trainers, unemployed, soldiers, managers, lawyers, drivers, etc.) in Slovakia. The minimum age of our research sample was 14, and maximum 71. As the data was collected via an online google platform, during the year 2020 , the snowball sampling or chain-referral sampling as a non-probability sampling technique, was used. This sampling technique is based on when the existing subjects provide referrals, to recruit samples required for a research study. The data was anonymised, respecting GDPR (Regulation of EU 2016/679, paragraph 26) and ethical principles, valid in Slovakia. A participant was informed with sufficiently detailed information on the study (about the study purpose, expected duration, study procedures, information on their right to decline or withdraw, and whom to contact for questions), so that they could make an informed, voluntary, and rational decision to participate.

The research group was divided into three age groups (a group of adolescents: $\mathrm{N}=240$, $\mathrm{M}_{\text {age }}=18.1, \mathrm{SD}=1.8$, young adults: $\mathrm{N}=487$, $M_{\text {age }}=23.5, S D=2.3$, an adulthood period group: $N=192, M_{\text {age }}=45.6, S D=9.2$, where not more than $2 \%$ of participants have not included their age) to fulfil a research question. Another research question analysed the differences in the concrete variables between omnivores $(\mathrm{N}=607)$ and vegetarians $(\mathrm{N}=85$, where $26 \%$ of participants have not categorised themselves into any of these groups), and also between a main participant's worldview (Christians: $\mathrm{N}=517$ and Atheists: $\mathrm{N}=265$, where $16 \%$ of participants have not declared any dominant world view or mentioned some minor orientations, e.g. agnostics, Buddhism, Yoga, "believe in God, but I am not a Christian", etc.). It can be concluded that our research sample was not representative, that is why further statistical correction analysis was used (e.g., effect size verification).

\section{Method}

We used two self-report measures:

$A n i \operatorname{Re}(15)$ is an instrument of one's own provenience, whose creation process, validity, and reliability assessment was described and explained in Studia Ecologiae et Bioethicae, last year (Kaliský and Kaliská 2020). It consists of 15 items, assessing the animal respect level labelled as $\mathrm{R}$-score ( $\mathrm{R}$ as respect), reaching values from 1 to 5 , with 5 representing the highest level of animal respect.

FEOAU (modified version of The Questionnaire of Ecocentric and Anthropocentric Attitudes Towards the Environment) assesses three dominant environmental orientations, ecocentric, anthropocentric, and apathic attitudes of a man to nature, and was used to verify the construct validity (its convergent and discriminant character). It consists of 27 items, assessing the attitude to environment, based on three aspects by Likert's 5-point scale of dis/agreement.

The respondents were questioned about other demographic facts related to their gender, age, professional status, place of living, worldview, and their eating habits, representing other contextual factors.

Research data was processed through the SPSS Statistics programme, version 19. Univariate and bivariate descriptive analyses were followed by inferential statistical methods. The research study is of correlation-differential study design.

\section{Research results}

The basic descriptive indicators for animal respect, R-score assessed by AniRe-Que (15), and three environmental orientations by FEOAU of our research sample, are presented in Table 1. To characterise the normal distribution of the analysed data set, measures of symmetry, skewness, and kurtosis were used. This enabled the use of parametric statistical analysis to answer our research questions. 
The normal distribution of the variables, measured by the AniRe-Que(15) and FEOAU questionnaires, was assessed on the basis of the descriptive characteristics of the normality distribution shape (coefficients of skewness and kurtosis). West and Finch (1996, in Cooper, Petrides 2010) claim that skewness and kurtosis in absolute values o-2 and $0-7$, are considered as values demonstrating univariate normality, so parametric tests for further analyses were used. The inner consistency calculated by Cronbach's alpha coefficients for each factor is considered as reaching highly acceptable values.

\section{RQ1: Can we support the construct validity of AniRe- Que(15) in the context of three environmental orientations? Are these factors determined also by a participant's age and gender?}

Construct validity of AniRe-Que(15) and its convergent-discriminant character was verified to three environmental attitudes from FEOAU, by the means of Pearson correlation analysis presented in Table 2 . We were also interested in a gender determined relation between these two constructs.

On the basis of the theoretical background, it was expected there would be positive relations between animal respect (from AniRe-Que/15/), and ecocentric attitudes (from the FEOAU questionnaire), supporting the convergent validity. This was supported for both genders, reaching highly significant positive and strong relations. Discriminant validity, predicted as almost up to zero (Urbánek at al. 2011), or negative (Maršálová and Mikšík 1990) relations between observed variables, was proved between the animal respect and anthropocentric and apathic attitudes. Both relations were highly significant, for both genders where animal respect was in a significant, negative, and weak relation to anthropocentric attitudes to nature, and in a significant negative and medium relation to apathic attitudes to nature. All the observed variables were not related to age, neither for any gender.
R02: Are there any significant gender differences in animal respect ( $R$-score) and three environmental attitudes from FEOAU?

Further on, we were interested in possible gender differences in our observed variables, by a parametric Student's t-test analysis for two independent samples; and the results are presented in Table 3.

It can be stated that females reached a significantly higher level of R-score from AniRe-Que(15) than males. Contrastingly, males reached a significantly higher level of anthropocentric attitudes and apathic attitudes to nature from the FEOAU questionnaire. We do realise that besides the statistical significance, there is also, importantly, the practical significance expressed by effect size. Cohen (1988) states that statistical significance as a p-value, is not a sufficient expression of differences between two independent research samples, for sometimes, the statistically significant difference has a trivial importance from a practical point of view, referring to a multiple sample (Sullivan and Feinn, 2012). It can be considered in the case of our research sample. Cohen (1988) formulated effect size differences calculated between two research samples, which means divided by a standard deviation being unrelated to the research sample size. There were stated conventional values enabling us to decide whether it is a huge $(d \geq 2.00)$, or very large $(2.00 \geq d \geq 1.20$; Sawilowsky 2009), or large $(\mathrm{d} \geq .80)$, medium $(.80 \geq \mathrm{d} \geq .50)$ or small $(\mathrm{d}<.5 \mathrm{O})$ effect size $(\mathrm{Co}-$ hen 1988), referring to practical (or clinical) difference significance (Hendl 2009). Calculating the effect size difference, we can conclude there is a small gender difference in all observed differences.

RQ3: Is there any significant difference between ecocentric attitude from the FEOAU and R-score from AniRe-Que(15) for each participant, and for both genders?

Then, we wanted to find out whether there are any gender differences between ecocentric attitudes assessed from the FEOAU and R-score estimated from AniRe-Que 
Table 1. Descriptive indicators of all variables in a sample of the Slovak respondents $(\mathrm{N}=919)$

\begin{tabular}{|c|c|c|c|c|c|c|c|c|c|}
\hline \multicolumn{2}{|l|}{ Indicators } & Min & Max & $\mathrm{AM}$ & SD & Median & Skewness & Kurtosis & $a$ \\
\hline AniRe-Que(15) & R-score & 1.67 & 5.0 & 3.79 & .62 & 3.8 & .448 & -.093 & .82 \\
\hline \multirow{3}{*}{ FEOAU } & $\begin{array}{l}\text { Anthropocentric } \\
\text { orientation }\end{array}$ & 1.0 & 5.0 & 3.37 & .76 & 3.38 & -.326 & -.215 & .76 \\
\hline & Ecocentric orientation & 1.75 & 5.00 & 4.34 & .55 & 4.50 & -1.127 & 1.357 & .82 \\
\hline & Apathic orientation & 1.00 & 4.71 & 1.96 & .70 & 1.86 & .738 & .365 & .74 \\
\hline
\end{tabular}

Table 2. Correlation analysis of R-score from AniRe-Que(15), three environmental attitudes from FEOAU questionnaire, participants' age and gender

\begin{tabular}{|c|c|c|c|c|c|c|}
\hline & & \multirow{3}{*}{ Indicators } & \multicolumn{3}{|c|}{ FEOAU questionnaire } & \multirow{3}{*}{ Age } \\
\hline & & & Anthropocentric & Ecocentric & Apathic & \\
\hline & & & \multicolumn{3}{|c|}{ orientation } & \\
\hline & & Female $(\mathrm{N}=523)$ & $-.172^{\star \star \star}$ & $.621^{\star \star \star}$ & $-.456^{\star \star \star}$ & -.030 \\
\hline $\begin{array}{l}\text { AniRe- } \\
\text { Que (15) }\end{array}$ & R-score & Male $(N=404)$ & $-.209^{\star \star \star}$ & $.656^{\star \star \star}$ & $-.448 * \star \star$ & .061 \\
\hline \multirow{6}{*}{ 륭 } & \multirow{3}{*}{ 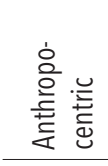 } & $N=936$ & & -.008 & $.273^{\star \star \star}$ & $.133^{\star \star \star}$ \\
\hline & & Female $(\mathrm{N}=523)$ & & -.027 & $.278^{\star \star \star}$ & -.064 \\
\hline & & Male $(\mathrm{N}=404)$ & & .022 & $.264^{\star \star \star}$ & $.172^{\star \star \star}$ \\
\hline & \multirow{3}{*}{ 兰 } & $\mathrm{N}=936$ & & & $-.487^{\star \star \star}$ & -.028 \\
\hline & & Female $(\mathrm{N}=523)$ & & & $-.505^{\star \star \star}$ & .101 \\
\hline & & Male $(\mathrm{N}=404)$ & & & $-.469^{\star \star \star}$ & -.082 \\
\hline \multirow{3}{*}{ Age } & & $\mathrm{N}=936$ & & & .030 & \\
\hline & & Female $(N=523)$ & & & $.101^{*}$ & \\
\hline & & Male $(\mathrm{N}=404)$ & & & -.082 & \\
\hline
\end{tabular}

$\mathrm{p} \leq .05^{*} \mathrm{p} \leq .01^{* * *} \mathrm{p} \leq .001^{* * * *}$

Table 3. Gender differences in the observed variables

\begin{tabular}{|c|c|c|c|c|c|c|c|c|}
\hline Indi & tors & Min & Max & AM & SD & t-test & $p$ & $d$ \\
\hline Females $(N=524)$ & \multirow{2}{*}{ R-score } & 1.67 & 5.00 & 3.85 & .61 & \multirow{2}{*}{3.366} & \multirow{2}{*}{.000} & \multirow{2}{*}{.23} \\
\hline Males $(N=405)$ & & 1.80 & 5.00 & 3.71 & .63 & & & \\
\hline Females $(\mathrm{N}=524)$ & \multirow{2}{*}{ Anthropo-centric } & 1.00 & 5.00 & 3.30 & .77 & \multirow{2}{*}{-2.917} & \multirow{2}{*}{.004} & \multirow{2}{*}{.20} \\
\hline Males $(N=405)$ & & 1.13 & 5.00 & 3.45 & .73 & & & \\
\hline Females $(\mathrm{N}=524)$ & \multirow{2}{*}{ Ecocentric } & 1.75 & 5.00 & 4.35 & .54 & \multirow{2}{*}{.768} & \multirow{2}{*}{.443} & \multirow{2}{*}{.06} \\
\hline Males $(N=405)$ & & 2.00 & 5.00 & 4.32 & .56 & & & \\
\hline Females $(N=524)$ & \multirow{2}{*}{ Apathic } & 1.00 & 4.71 & 1.89 & .65 & \multirow{2}{*}{-3.361} & \multirow{2}{*}{.001} & \multirow{2}{*}{.23} \\
\hline Males $(N=405)$ & & 1.00 & 4.43 & 2.05 & .74 & & & \\
\hline
\end{tabular}

(15). This difference was calculated by a paired t-test, used when we are interested in the difference between two variables for the same subject. The results are presented in Table 4.

Table 4 presents the results of paired t-test analyses. It can be concluded there is a significant difference between R-score assessed by AniRe-Que(15), and Ecocentric attitudes from the FEOAU, with a large effect size difference. This difference is in favour to a higher level of ecocentric attitudes towards nature. 
RQ4: Are there any significant differences between three age groups in the animal respect score and three environmental orientations?

Further analysis was based on the interest to find out the differences between three age groups in the animal respect score, and three environmental attitudes, according to the statistical procedure of ANOVA. We split our research group into three age groups. The first one is a group of adolescents $\left(\mathrm{N}=240, \mathrm{M}_{\mathrm{age}}=18.1, \mathrm{SD}=1.8\right)$, young adults $\left(\mathrm{N}=487, \mathrm{M}_{\text {age }}=23.5, \mathrm{SD}=2.3\right)$, and a group covering the whole period of adult$\operatorname{hood}\left(\mathrm{N}=192, \mathrm{M}_{\mathrm{age}}=45.6, \mathrm{SD}=9.2\right)$. The F-test was significant for all observed variables. Then, we conducted a PostHoc test to find out the in-between group differences, presented in Table 5.

Table 5 presents the results of three age group analyses. It can be concluded that there is a significant difference in the R-score assessed by AniRe-Que(15), only between the adolescents and young adults, in favour to young adults, in anthropocentric attitudes by FEOAU between adolescents and adults, and young adults and adults always in favour to older adults, in ecocentric attitudes only between adolescents and young adults, in favour to young adults. In the apathic orientation towards nature, there is a difference between adolescents and young adults, in favour to adolescents, and between young adults and adults, in favour to adults. All of these differences are of a small effect size difference.

RQ5: Can we support the criterion validity of AniReQue(15) in the context of Omnivores and Vegetarians?

As we have done in our previous study (Kaliský and Kaliská 2020), we were analysing the criterion validity by the means of known groups (Maršálová and Mikšík 1990), which was a group of the animal rights defenders. Now, we were trying to find out the same tendency, and prove again the criterion validity between those people who do eat/ like to eat meat $(\mathrm{N}=607 ; 51 \%$ of females) and those people who do not eat meat or/

Table 4. The differences between ecocentric attitudes and R-score for each participant, and for both genders

\begin{tabular}{|c|c|c|c|c|c|c|c|c|}
\hline \multicolumn{2}{|c|}{ Indicators } & Min & $\operatorname{Max}$ & $\mathrm{AM}$ & SD & t-test & $p$ & $d$ \\
\hline \multirow[t]{2}{*}{$N=933$} & R-score & 1.67 & 5.00 & 3.79 & .62 & \multirow{2}{*}{-32.90} & \multirow{2}{*}{.000} & \multirow{2}{*}{.94} \\
\hline & Ecocentric & 1.75 & 5.00 & 4.34 & .55 & & & \\
\hline \multirow{2}{*}{$\begin{array}{l}\text { Females } \\
(\mathrm{N}=523)\end{array}$} & R-score & 1.67 & 5.00 & 3.85 & .61 & \multirow{2}{*}{-22.52} & \multirow{2}{*}{.000} & \multirow{2}{*}{.87} \\
\hline & Ecocentric & 1.75 & 5.00 & 4.35 & .54 & & & \\
\hline \multirow{2}{*}{$\begin{array}{l}\text { Males } \\
(\mathrm{N}=404)\end{array}$} & R-score & 1.80 & 5.00 & 3.71 & .63 & \multirow{2}{*}{-24.48} & \multirow{2}{*}{.000} & \multirow{2}{*}{1.02} \\
\hline & Ecocentric & 2.00 & 5.00 & 4.32 & .56 & & & \\
\hline
\end{tabular}

Table 5. Three age group differences in the observed variables

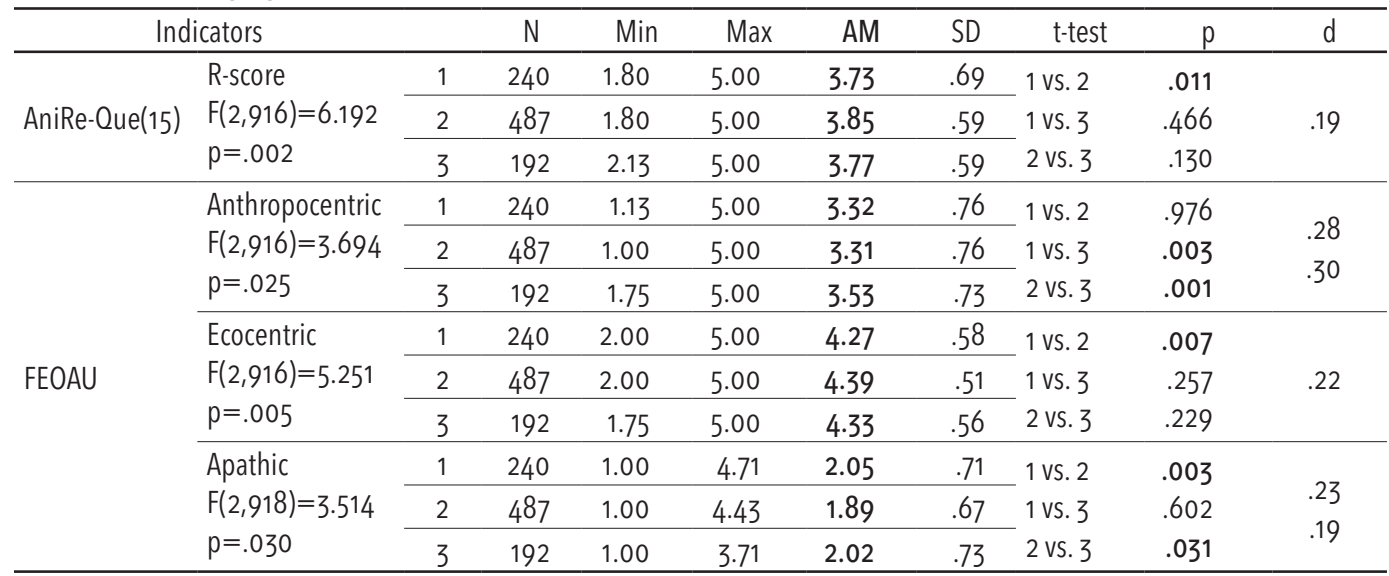


are vegetarians for various reasons $(\mathrm{N}=85$; $68 \%$ of females). Their animal respect was predicted by their eating-habits. It has been presupposed this group would have reached a significantly higher level of animal respect from AniRe-Que(15), ecocentric tendency from the FEOAU questionnaire, and a lower level of anthropocentric and apathic orientation from the FEOAU in our research group. Table 6 presents the results of the searched differences by a parametric Student's t-test analysis for both groups.

It can be stated that our vegetarians reached a significantly higher level of R-score from AniRe-Que(15) than Omnivores from our research sample. The effect size difference showed a very large practical difference in this case. The vegetarians also proved a significantly higher level of ecocentric orientation to nature, with a medium effect size. Our Omnivores reached a significantly higher level of anthropocentric and apathic orientation to nature, with a medium effect size.

R06: Are there any significant differences in animal respect ( $R$-score) and three environmental attitudes from the FEOAU in the context of a participant's worldview?

Further on in the project, we were interested in a possible participant's worldview differences in our observed variables, by a parametric Student's t-test analysis for two independent samples presented in $\mathrm{Ta}$ ble 7 .

Our interest to search a participant's worldview differences, found the participants labelling themselves as atheists, and reached a significantly higher level of R-score from AniRe-Que(15), with a small effect size as a practical difference level. The Christians reached a significantly higher level of anthropocentric and apathic orientations to nature, with a small to medium effect size.

RQ7: Are there any significant differences in animal respect ( $R$-score) and three environmental attitudes from the FEOAU in the context of a participant's place of living?

The last analysis was based on a participant's place of living differences, classified into five categories of rural villages of up to 2,000 inhabitants, then a place of up to 5,000 inhabitants, then up to 20,000 inhabitants as a town, up to 70,000 inhabitants, and more than 70,000 inhabitants as a city, in our observed variables. Statistical procedure of ANOVA for R-score $/ \mathrm{F}(4,925)=2.945, \mathrm{p}=.02 \mathrm{O} /$, for anthropocentric orientation $/ \mathrm{F}(4,923)=3.722, \mathrm{p}=.005 /$ and apathic orientation $/ \mathrm{F}(4,923)=3.968, \mathrm{p}=.003 /$ proved to be the significant difference between the observed variables, in the context of a participant's place of living, based on

Table 6. Declared eating habit differences between two groups (Omnivores vs. vegetarians)

\begin{tabular}{|c|c|c|c|c|c|c|c|c|c|}
\hline \multicolumn{3}{|c|}{ Indicators } & Min & Max & AM & SD & t-test & $p$ & d \\
\hline Omnivores $(\mathrm{N}=607)$ & \multirow{2}{*}{$\begin{array}{l}\text { AniRe- } \\
\text { Que(15) }\end{array}$} & \multirow[t]{2}{*}{ R-score } & 1.67 & 5.00 & 3.58 & .58 & \multirow{2}{*}{-16.055} & \multirow{2}{*}{.000} & \multirow{2}{*}{1.67} \\
\hline Vegetarian $(\mathrm{N}=85)$ & & & 2.60 & 5.00 & 4.44 & .44 & & & \\
\hline Omnivores $(\mathrm{N}=607)$ & \multirow{6}{*}{ 롫 } & 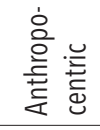 & 1.13 & 5.00 & 3.48 & .73 & \multirow[t]{2}{*}{4.238} & \multirow[t]{2}{*}{.000} & \multirow[t]{2}{*}{.50} \\
\hline Vegetarian $(\mathrm{N}=85)$ & & & 1.50 & 4.63 & 3.10 & .78 & & & \\
\hline Omnivores $(\mathrm{N}=607)$ & & \multirow{2}{*}{ 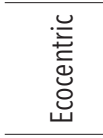 } & 2.00 & 5.00 & 4.28 & .56 & \multirow[t]{2}{*}{-5.227} & \multirow[t]{2}{*}{.000} & \multirow[t]{2}{*}{.59} \\
\hline Vegetarian $(\mathrm{N}=85)$ & & & 1.75 & 5.00 & 4.60 & .53 & & & \\
\hline Omnivores $(\mathrm{N}=607)$ & & \multirow{2}{*}{ 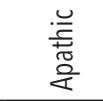 } & 1.00 & 4.71 & 2.10 & .70 & \multirow[t]{2}{*}{7.392} & \multirow[t]{2}{*}{.000} & \multirow[t]{2}{*}{.79} \\
\hline Vegetarian $(\mathrm{N}=85)$ & & & 1.00 & 4.14 & 1.59 & .58 & & & \\
\hline
\end{tabular}


the number of its inhabitants, as presented in Table 8.

Searching for the differences in the animal respect score from AniRe-Que(15), in the context of a participant's place of living, the only significant difference proved to be only between a rural village of less than 2,00o inhabitants, and cities of more than 70,000 inhabitants, with a small effect size in favour to city participants.

Considering the anthropocentric and apathic orientations to nature, it can be concluded that the bigger the city is, the less anthropocentric and apathic orientations dominate our participants, with small effect sizes.
There were no significant differences in ecocentric orientations to nature, based on the number of inhabitants in a place of living of our participants.

\section{Discussion}

We found that the R-score enters into a significant positive and strong relationship with the ecocentric attitude of the FEOAU questionnaire, confirming the convergent validity of the AniRe-Que(15) construct validity. Furthermore, the R-score enters into a highly significant negative, moderately strong relationship with an apathic attitude towards nature, and a low negative relationship with an anthropocentric attitude towards nature, confirming the discriminant validity

Table 7. Participant's worldview differences in the observed variables

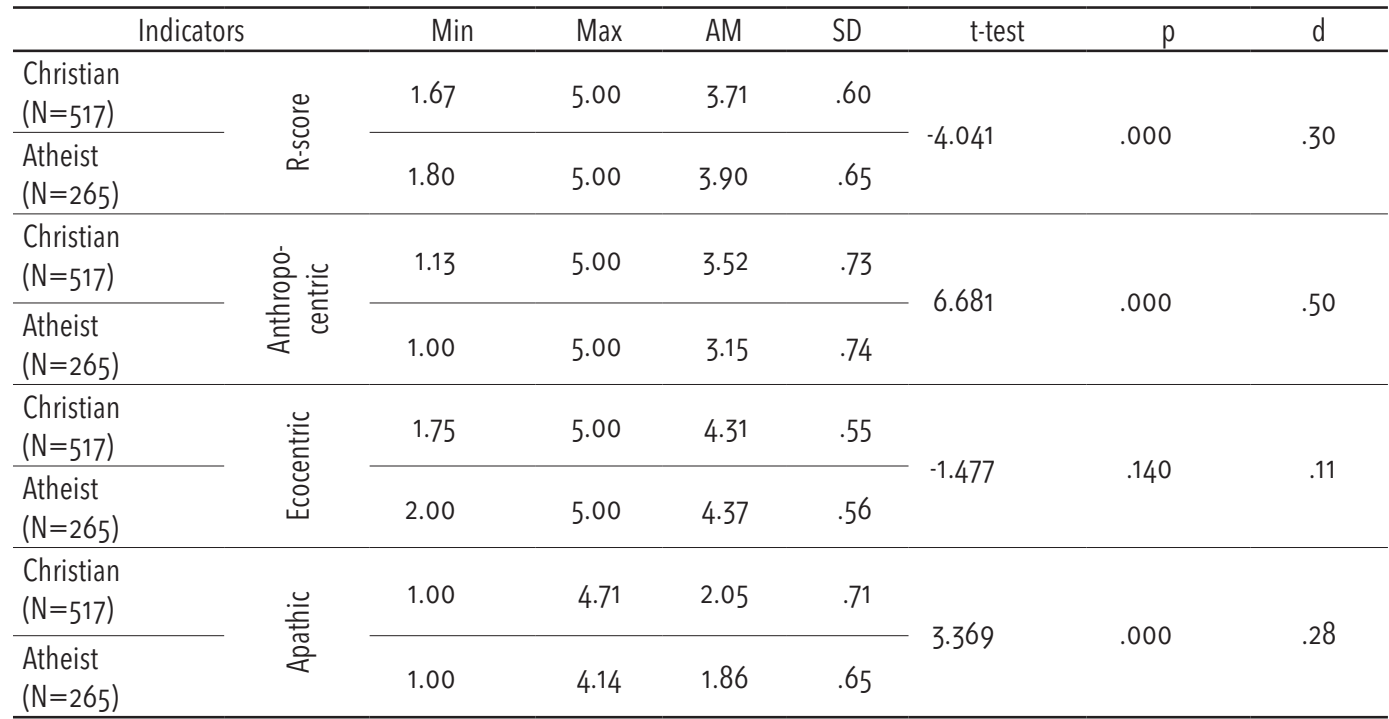

Table 8. Participants' place of living differences in the observed variables

\begin{tabular}{|c|c|c|c|c|c|c|c|}
\hline Indicators & Min & $\operatorname{Max}$ & AM & SD & t-test & $p$ & d \\
\hline Rural $(N=300)$ & 1.80 & 5.00 & 3.72 & .61 & \multirow{2}{*}{ Rural/City 3.345} & \multirow{2}{*}{.001} & \multirow{2}{*}{.45} \\
\hline City $(\mathrm{N}=70)$ & 1.80 & 5.00 & 4.00 & .63 & & & \\
\hline Rural $(N=300)$ & 1.25 & 5.00 & 3.44 & .75 & Rural/Town & \multirow{2}{*}{.001} & \multirow{2}{*}{.38} \\
\hline Anthropo-centric & 1.00 & 4.63 & 3.15 & .78 & 3.511 & & \\
\hline City $(N=70)$ & 1.38 & 4.75 & 3.26 & .80 & Rural/City 1.739 & .085 & .23 \\
\hline Rural $(N=300)$ & 1.00 & 4.71 & 2.04 & .70 & Rural/Town & \multirow{2}{*}{.007} & \multirow{2}{*}{.29} \\
\hline Town $(\mathrm{N}=120)$ & 1.00 & 4.71 & 1.83 & .75 & 2.725 & & \\
\hline City $(N=70)$ & 1.00 & 4.14 & 1.77 & .67 & $\begin{array}{l}\text { Rural/City } \\
3.000\end{array}$ & .003 & .39 \\
\hline
\end{tabular}


of the AniRe-Que(15) construct validity. These were expected values and comparable to our previous research from 2019-2020 (Kaliský and Kaliská, 2020). The same tendency was supported also by the analysis done for the genders.

So, then, we were interested in the gender differences in our observed variables. We found out that women declare a higher level of respect for animals than men (AM = 3.85 vs. $A M=3.71, p=.000$ ), and are significantly less anthropocentric and less indifferent to nature than men. We assume that the gender difference, in respect for animals, is related to a female's caring morality (Gilliganová 2001; Koleva et al. 2014), gender related higher emotionality and empathy (Hills 1993), and a more natural expression of compassion. On the other hand, males are more frequently powerful, dominant, technical, or possessing controlling attitude towards the world. According to the gender cliché, a male is one who does not succumb to sentiment. However, it is a fact that we did not measure, whether the females in our research group, were really more sensitive, empathetic, and caring than males. A significant gender gap, in favour of females, was also found in research by other authors, who examined human attitudes toward animals (e.g., Siegrist 1996; Schultz et al. 2000; Herzog et al. 1991; Mathews and Herzog 1997; Heleski et al. 2006; Schenk et al. 1994; Plous 1991).

In the context of age, we did not find a relationship with any observed variable. That is why we were trying to find out the differences in our observed variables, on the basis of three age groups, wondering about the developmental influences on our variables. We divided our research sample into three age groups, i.e., adolescents, young adults, and adulthood (up to 20 years, 2130 years, 31+ years). The twenties achieved the highest R-score, the highest level of ecocentric orientation, the lowest level of apathic and also anthropocentric orientations. It is a coherent attitude towards the animals, and nature itself. We found a statistically significant difference in the R-score (and also in the ecocentric orientation) between adolescents and young adults, and in the anthropocentric orientation between adults and two younger age groups of our respondents. As the R-score expresses respect for animals and does not take into account possession of animals, this tendency may explain lower scores for adolescents, who often own animals for utilitarian and hedonistic reasons. A similar tendency was explained by Kidd and Kidd (1990), who in their sample of 300 respondents, proved that children and adolescents (ages 3-18) usually own pets for entertainment. An idealistic relationship with the world is typical of the young adults, as they fulfil their own individual emancipation. It seems this allows them to be the first ones to fight for animal rights, and to preserve nature's conservation. However, the group of (older) adults usually have the tendency to lead their lives, in the context of respecting the civic and economic pragmatic values of securing their own families, predisposing them to an anthropocentric style of self-realisation.

In the context of a participant's worldview, we considered only the comparison of groups with Christian $(\mathrm{N}=517)$ and Atheistic $(\mathrm{N}=265)$ orientation, other groups were rather small for comparison, covering various minor religions, (e.g., Muslims, Buddhists, Yogis), or those religiously oriented, but without any specific denomination). We found a significant difference in anthropocentric environmental attitudes between participants declaring Christian worldview dominancy $(A M=3.52)$ to the atheistic worldview $(A M=3.15)$. This finding corresponds with the critical remarks of such authors as E. Kohák (2010), E. Drewermann (1993), and others, who point out that in the interpretation of biblical texts, the focus should not be on man, but on God and his work, that the Christian ethical system should be theocentric, not anthropocentric. Whether we interpret man from the biblical message as the master and conqueror of nature, or as a responsible shepherd called out 
by God, both ideas have in their focus, man and not God (Kohák 2010, 73). L. White (1967) began this discussion on environmental attitudes, with respect to the biblical message by studying 'The Historical Roots of Our Ecological Crisis becoming an inspirational first for theoretical and then empirical verifications (e.g., Chandler 1993; Guth et al. 1995; Hand et al. 1984; Hartwig 1999). A similar hypothesis (to our belief that the worldview is related to the environmental attitude), was postulated by Schultz et al. (200o), who examined people whose worldview is more dependent on biblical texts, and at the same time, scored higher in anthropocentric and lower in ecocentric environmental orientations towards nature, using the same questionnaire by Thompson and Barton, as used in our research. Their research was the first one verifying White's hypothesis, based on an international study drawing the conclusion from a sample of 2,160 respondents from 14 countries (13 countries in North and South America, plus Spain). We do not claim that the Christian orientation leads to a lack of interest in environmental problems, only that its interest is rooted in the interconnectedness of environmental problems to man. However, we did not prove a statistically significant difference in ecocentric environmental orientation, the context of a participant's worldviews. The Christians, did achieve, though, a significantly lower R-score in our research sample $(\mathrm{AM}=3.71$ vs. $\mathrm{AM}=3.90)$. A similar finding can be found in Templer et al. (2006), Bowd and Bowd (1989), Galvin and Herzog (1992), DeLeeuw et al. (2007). However, this issue is more complex, and would need to be addressed more comprehensively for further statements and predictions.

Statistical analysis proved that the number of inhabitants of a participant's permanent residence, does not relate to the ecocentric environmental attitudes of our research sample, but the anthropocentric orientation is more pronounced for rural respondents, than for those ones living in a city, with more than 70,000 inhabitants (the difference is statistically significant). Apathic environmental orientation towards nature is more typical for respondents living in the countryside than in a bigger city. The R-score variable also corresponds to these findings. Statistically significant higher R-scores were achieved by the respondents living in a large city, compared to the countryside. It seems that the town or city people do care more about animals and nature protection. We assume that the reason for this attitude is a daily confrontation with the polluted living, urban environment, and also less opportunity for farming and animal caring than with a market commodity.

The final and very important finding is that the attitude towards nature, expressed in general attitude, does not completely coincide with the attitude towards animals. This finding points to the fact that not all natural beings are treated with equal respect by our respondents. We found out that the self-expressed respect for animals ( $\mathrm{R}$-score, $\mathrm{AM}=$ $3.79, \mathrm{~N}=919$ ) is lower than the respect for nature itself, self-declared in the ecocentric environmental attitude $(\mathrm{AM}=4.34)$ of our research sample, and this difference is highly significant $(\mathrm{p}=.000)$ with a large effect size representing a practical difference between these two variables. Therefore, we believe that diagnostic tools thematising nature in its general (complex, synthesising) expression, are not sufficient to determine or discover the respondents' attitudes, only towards animals. We claim that our respondents protect nature, but they do care less about animals. Thus, we come to the hypothesis that respondents do protect nature, because of other natural entities (or functions), and thus, the achieved high score in the ecocentric environmental orientation, refers to the attitude towards animals only indirectly, and probably, also inaccurately. We also found that a high respect for animals is in a strong, positive relationship with the ecocentric environmental attitude towards nature $(r=.63)$, and in a moderately negative relationship with the apathic attitude $(r=-.46)$ being true for both genders. 
We also assumed that it would be in a significant negative relationship to the anthropocentric attitude towards nature, but this was confirmed only by a small tendency $(r=-$ .20). We explain this relationship in the context of the ecological tendencies of Western civilisation for nature protection, especially present in anthropocentric ethics. Another explanation for this intertwining of eco-centrism and anthropocentrism is in the understanding of man as a part of nature and a member of the animal kingdom; therefore, in respect of beings with feelings, self-respect is also necessarily included. From this analysis, we assume that the relationship between anthropocentric and ecocentric environmental attitudes should practically never reach a negative value of strong intensity, as this would reveal certain escape tendencies of man's self-denial or self-destruction.

\section{Conclusions}

In the research, we applied the author's 15 -item questionnaire of human-animal relationship AniRe-Que(15), based on the ecological theory of bio-centric egalitarianism covering non-human beings' respect and their consideration. We consider this questionnaire to be a unique one, as there are no tools based on the ecological theory of bio-centric egalitarianism so far. We have analysed its construct validity by Thompson and Barton's questionnaire (aimed at anthropocentric, ecocentric and apathic environmental orientation) and in the sociological context variables (such as gender, age, eating habits, worldview, place of living). In the further research, it would be interesting to continue the validation process verification of AniRe-Que(15), in the context of other diagnostic tools assessing nature, and also in the international context. This creates an opportunity for international co-operation that is welcomed by the study's authors. The need to use psychometrically valid and reliable tools, respects a demand of human sciences, to be able to assess the status quo, and a demand of educational sciences to be able to find out the applied educational programme's effectiveness, aimed at ecological intelligence (Goleman 2009) development and facilitation.

Author Contributions: Conceptualization, J.K.; Methodology, J.K. and L.K.; Validation, L.K.; Formal Analysis, L.K.; Investigation, J.K.; Writing - Original Draft Preparation, J.K. and L.K.; Writing - Review \& Editing, J.K. and L.K.; Visualization, J.K.; Supervision, J.K. Both authors have read and agreed to the published version of the manuscript.

Funding: This research received no external funding. Institutional Review Board Statement: Not applicable.

Conflicts of Interest: The authors declare no conflict of interest.

\section{References}

Bowd, Alan D., and Anne C. Bowd. 1989. "Attitudes toward the treatment of animals: A study ofChristian groups in Australia." Anthrozoös 3: 20-24. http:// dx.doi.org/10.2752/089279390787057784.

Cohen, Jacob. 1988. Statistical Power Analysis for The Behavioral Science. Hillsdale (NJ): Erlbaum. Cooper, Andres, and Konstantinos V. Petrides. 2010. "A Psychometric Analysis of the Trait Emotional Intelligence Questionnaire-Short Form (TEIQue-SF) Using Item Respond Theory." Journal of Personality Assessment 92 (5): 449-457.

DeLeeuw, Jamie L., Luke W. Galen, Cassandra Aebersold, and Victoria Stanton. 2007. "Support for animal rights as a function of belief in evolution, religious fundamentalism, and religious denomination." Society $\mathcal{E}$ Animals 15: 353-363. http://dx.doi.org/10.1163/156853007X235528.

Drewermann, Eugen. 1998. O nesmrtelnosti zvírat. Košice: Knižná dielňa Timotej.

Dunlap, Riley E., and Kent D. Van Liere. 1978. "The "new environmental paradigm": A proposed measuring instrument and preliminary results." Journal of Environmental Education 9: 10-19.

Galvin, Shelley L., and Harold A. Herzog Jr. 1992. "Ethical ideology, animal rights activism, and attitudes toward the treatment of animals." Ethics E Behavior 2 (3): 141-149.

Gilliganová, Carol. 2001. Jiným hlasem. Praha: Portál. Goleman, David, 2009. Ecological Intelligence: The Hidden Impacts of What We Buy. New York: Broadway Books. 
Guth, James L., Lyman A. Kellstedt, Corvin E. Smidt, John Green. 1995. "Faith and the environment: Religious beliefs and attitudes on environmental policy." American Journal of Political Science 39: 364-382.

Hand, Carl, and Kent Van Liere. 1984. "Religion, mastery-over-nature, and environmental concern." Social Forces 57: 265-281.

Hartwig, Boyd H. 1999. "Christianity and the environment in the American public." Journal for the Scientific Study of Religion 38: 36-44.

Heleski, Camie R., Angela G. Mertig, and Adroaldo J. Zanella. 2006. "Stakeholder attitudes toward farm animal welfare.” Anthrozoös 19: 290-307. http://dx.doi.org/10.2752/089279306785415439.

Hendl, Jan. 2009. Přehled statistických metod. Praha: Portál.

Herzog, Harold A. Jr., Nancy S. Betchart, and Robert B. Pittman. 1991. "Gender, sex role orientation, and attitudes toward animals." Anthrozoös 4: 184-191. http://dx.doi.org/10.2752/089279391787057170.

Hills, Adelma M. 1993. "The motivational bases of attitudes toward animals." Society \& Animals 1 (2): 111-128. http://dx.doi org/10.1163/156853093X00028.

Chandler, Edward W. 1993. "Anthropocentrism: Construct validity and measurement." Doctoral dissertation, Louisiana State University and Agricultural \& Mechanical College. Accessed November 2021. https:// digitalcommons.lsu.edu/cgi/viewcontent. cgi article $=4588 \&$ context $=$ gradschool_disstheses

Kaliský, Ján, Lada Kaliská. 2020. “Man’s attitude towards nature and animal respect questionnaire (AniRe-Que)." Studia Ecologiae et Bioethicae 18 (4): 29-37.

Kidd, Aline H., and Robert M. Kidd. 1990. "Social and environmental influences on children's attitudes toward pets." Psychological Reports 67: 807- 818 https://doi.org/10.2466/PR0.67.7.807-818.

Kohák, Erazim. 2010. Zelená svatozář. Praha: Slon. Kolářský, rudolf. 2011. Filosofický význam současné ekologické krize. Praha: Filosofia.

Koleva, Sena, Dylan Selterman, Hannah Kang, and Jesse Graham. 2014. Beyond Kohlberg vs. Gilligan: Empathy and Disgust Sensitivity Mediate Gender Differences in Moral Judgments. http://dx.doi. org/10.2139/ssrn.2486030.
Krajhanzl, Jan. 2014. Psychologie vztahu k přírodě a životnímu prostředí. Brno: Lipka, MUNI press. Maršálová, Libuše, and Oldřich Mikšík. 1990. Metodológia a metódy psychologického výskumu. Bratislava: SPN.

Mathews, Steve, and Harold A. Herzog. 1997. "Personality and attitudes toward the treatment of animals." Society \& Animals 5: 169-175. http:// dx.doi.org/10.1163/156853097X00060.

Milfont, Taciano, and John Duckitt. 2010. "The environmental attitudes inventory: A valid and reliable measure to assess the structure of environmental attitudes." Journal of Environmental Psychology 30: 80-94.

Nakonečný, Milan. 1998. Základy psychologie. Praha: Academia.

Pirrone, Frederica, Chiara Mariti, Angelo Gazzano, Mariangela Albertini, Claudio Sighieri, and Silvana Diverio. 2019. "Attitudes toward Animals and Their Welfare among Italian Veterinary Students." Veterinary sciences 6 (1): 19. https:// doi.org/10.3390/vetsci6010019.

Plous, Scott. 1991. "An attitude survey of animal rights activists." Psychological Science 2: 194-196. https://doi.org/10.1111/j.1467-9280.1991.tb00131.x.

Regan, Tom. 1985. "The Case for Animal Rights." In In Defense of Animals, edited by Peter Singer, 13-26. New York: Basil Blackwell.

Regan, Tom. 1997. "Wie man Rechte für Tiere begründet." In Naturethik, edited by Angelika Krebs. Frankfurt: Suhrkamp.

Sawilowsky, Shlomo S. 2009. "New effect size rules of thumb." Journal of Modern Applied Statistical Methods 8(2): 597-599.

Schenk, Suzanne A., Donald I. Templer, Noel B. Peters, and Mari Schmidt. 1994. "The genesis and correlates of attitudes toward pets." Anthrozoös 7: 60-68. http://dx.doi.org/10.2752/089279394787002041.

Schultz, Paul, Lynnette Zelezny, Nancy Dalrymple. 2000. "A Multinational Perspective on the Relation Between Judeo-Christian Religious Beliefs and Attitudes of Environmental Concern." Environment and Behavior 32(4): 576-591. https:// doi.org/10.1177/00139160021972676.

Schweitzer, Albert. 1974. Nauka úcty k životu. Praha: Lyra Pragensis.

Siegrist, Michael. 1996. "Messung der Umwelteinstellung." Zeischrift für Socialpsychologie, Num. 27. Bern: Hans Huber. 
Skýbová, Marie. 2011. Etika a př́roda. Červený Kostelec: Pavel Mervart.

Sullivan, Gail M., and Richard Feinn. 2012. "Using Effect Size - or Why the P-Value Is Not Enough." Journal of Graduate Medical Education 4 (3): 279-282.

Taylor, Paul W. 1986. Respect for Nature. A Theory of Environmental Ethics. Princeton: Princeton University Press.

Templer, Donald I., Heather J. Connelly, Lynette Bassman, and Jessica Hart. 2006. "Construction and validation of an Animal-Human Continuity
Scale." Social Behavior and Personality 34: 769 776. http://dx.doi.org/10.2224/sbp.2006.34.7.769.

Thompson, Suzanne C. G., and Michaelle A. Barton. 1994. "Ecocentric and anthropocentric attitudes toward the environment." Journal of Environmental Psychology 14: 149-157.

Urbánek, Tomáš, Denisa Denglerová, and Jan Širuček. 2011. Psychometrika. Měřenív psychologii. Praha: Portál.

White, Lynn. 1967. "The Historical Roots of Our Ecologic Crisis.” Science 155 (3767): 1203-1207. http://dx.doi.org/10.1126/science.155.3767.1203. 